Marić, D., Stanić, M. (2021): Bioaccumulation of 18 traces metal in muscle and exoskeleton in the noble crayfish (Astacus astacus l.) In the river Zeta (Montenegro). Agriculture and Forestry, 67 (3): 31-42.

DOI: 10.17707/AgricultForest.67.3.03

\title{
Drago MARIĆ , Mira STANIĆ \\ BIOACCUMULATION OF 18 TRACE METALS IN MUSCLE AND EXOSKELETON IN THE NOBLE CRAYFISH (ASTACUS ASTACUS L.) IN THE RIVER ZETA (MONTENEGRO)
}

\section{SUMMARY}

This study assessed the level of heavy metals accumulation in abdominal muscle and exoskeleton on of Astacus astacus L. collected from Zeta River in July, with the aim of predicting health risk effect on human consumers. Noble crayfish samples were collected from four different sites along the river. The concentration of metals in the muscle and chitin of the Noble crayfish was determined using atomic absorption spectrophotometer. The exoskeleton showed a decidedly higher content of most analysed trace elements with respect to muscles (two- to fourfold higher for $\mathrm{Al}, \mathrm{Ca}$; two-to eightfold for $\mathrm{Fe}$ and ten times higher for $\mathrm{Sn}$ and $\mathrm{Mn}$ ). $\mathrm{Hg}, \mathrm{K}, \mathrm{Mg}$ and $\mathrm{Zn}$ were found in higher concentrations in the abdominal muscle in Noble crayfish from the River Zeta. Nonsignificant differences were found between muscles and exoskeleton for $\mathrm{As}, \mathrm{Cu}, \mathrm{K}, \mathrm{Na}, \mathrm{Ni}$, and $\mathrm{Si}$ (except first locality). Muscle content analysis had indicated that sampling point I (first) had the lowest concentration and sampling point IV (the last) had the highest concentration of accumulated heavy metals. It was believed that domestic activities around the river the major contributing factor to the accumulation of toxic heavy metals in muscle and carapace sample analysed, it is recommended that intervention relevant authorities are needed to curtail chemical degradation of the aquatic biota over a period of time. The most of trace element concentrations found in crayfish tissues were in the range considered harmful to human health (except for $\mathrm{Na}, \mathrm{Ni}, \mathrm{Sn}$ and $\mathrm{Cr}$ ). We hypothesize that A. astacus in the Zeta River aquatic communities can act as a vector of pollutants, as crayfish can transfer their relatively high amount of heavy metals to higher trophic levels.

Keywords: Bioaccumulation, heavy metals, crayfish muscle Exoskeletonon, pollution, Montenegro.

\section{INTRODUCTION}

The Noble crayfish (Astacus astacus L.) stands as an important food in many parts of the Europe, being a rich source of protein. It is a commercial

\footnotetext{
${ }^{1}$ Drago Marić, (corresponding author: dragomrc@yahoo.com), Department of Biology, Faculty of Sciences, University of Montenegro, Podgorica, MONTENEGRO

${ }^{2}$ Mira Stanić, Gymnasium "Stojan Cerović" Nikšić, MONTENEGRO

Notes: The authors declare that they have no conflicts of interest. Authorship Form signed online. 
species in Montenegro. In the past, it was hunted in larger quantities (Marić and Rajković, 2004), and lately in much smaller ones, but there is no reliable data on that. In general, commercial hunting of all freshwater species is in significant decline (Marić, 2018; Pešić et al. 2019), and the causes have not been studied in detail. The health safety of aquatic organisms used for commercial purposes has also not been well and comprehensively studied. Only some species of fish have been studied in more detail from the aspect of bioaccumulation of heavy metals in muscles (Rakočević et al. 2018). The Noble crayfish has not been studied from this aspect. The commercial aspect and the lack of data on the quality of meat of this type are the main reasons for the research of metals presented in this paper.

In the least hundred years, a significant increase in the concentration of metals in the environment has been recorded (Vamerali et al. 2010). Heavy metals of natural and anthropogenic sources are released into aquatic ecosystems, where they pose a serious threat because of their toxicity, long persistence, bioaccumulation and biomagnifications in the food chain (Zhou et al. 2008). Aquatic invertebrates are sensitive to metals in their environment and are mostly used to assess aquatic ecosystem quality (Bonada et al. 2006). They can accumulate metals directly from the sediments or by food and, based on their life cycle, some species can accumulate more elements than the others (Pourang 1996). Heavy metals affect living organisms in various ways; some have essential functions (e.g. $\mathrm{Cu}, \mathrm{Mn}$ and $\mathrm{Zn}$ ) contributing to the maintenance of a good health in humans and animals (Rainbow 2007) and are toxic only at high levels, whereas others are xenobiotic: non-essential metals as $\mathrm{Pb}$ and $\mathrm{Hg}$ do not play any role in metabolism and are toxic even at low concentrations (Kouba et al. 2010). The aim of present work was to characterize heavy metal content in selected tissues of noble crayfish samples collected from different sites of the River Zeta in order to assess bioaccumulation mechanisms, evaluate whether these concentrations could be considered harmful for human health and, finally, to identify possible sources of contamination in the study area. We exploited the selective metal bioaccumulation in two different tissues of A. astacus, exoskeletonon, and abdominal muscle, which is the edible part. There is very scarce information on heavy metal distribution in biota of this area, in spite of the presence of many industrial and agricultural activities.

\section{Area and habitat study}

\section{MATERIAL AND METHODS}

Nikšic field is situated in the western part of the Republic of Montenegro. It is situated between $18^{\circ} 30^{\prime}$ to $19^{\circ} 10^{\prime}$ of eastern geographical longitude and $42^{\circ}$ $42^{\prime}$ to $42^{\circ} 53^{\prime}$ of northern geographical latitude on the altitude of around 600$630 \mathrm{~m}$ (Figure 1). The main water course of Nikšićko polje (field) is the so coaled Gornja Zeta (the Upper Zeta). The length of the River Gornja Zeta is around 15 $\mathrm{km}$ counting from the confluence of the Rastovac and the Sušica, than it disappears under the ground and appears again on the spring Glava Zete on peak 
elevation of $50 \mathrm{~m}$. There are three artificial lakes Krupac, Slano and Liverovići. The Noble crayfish also live in them.

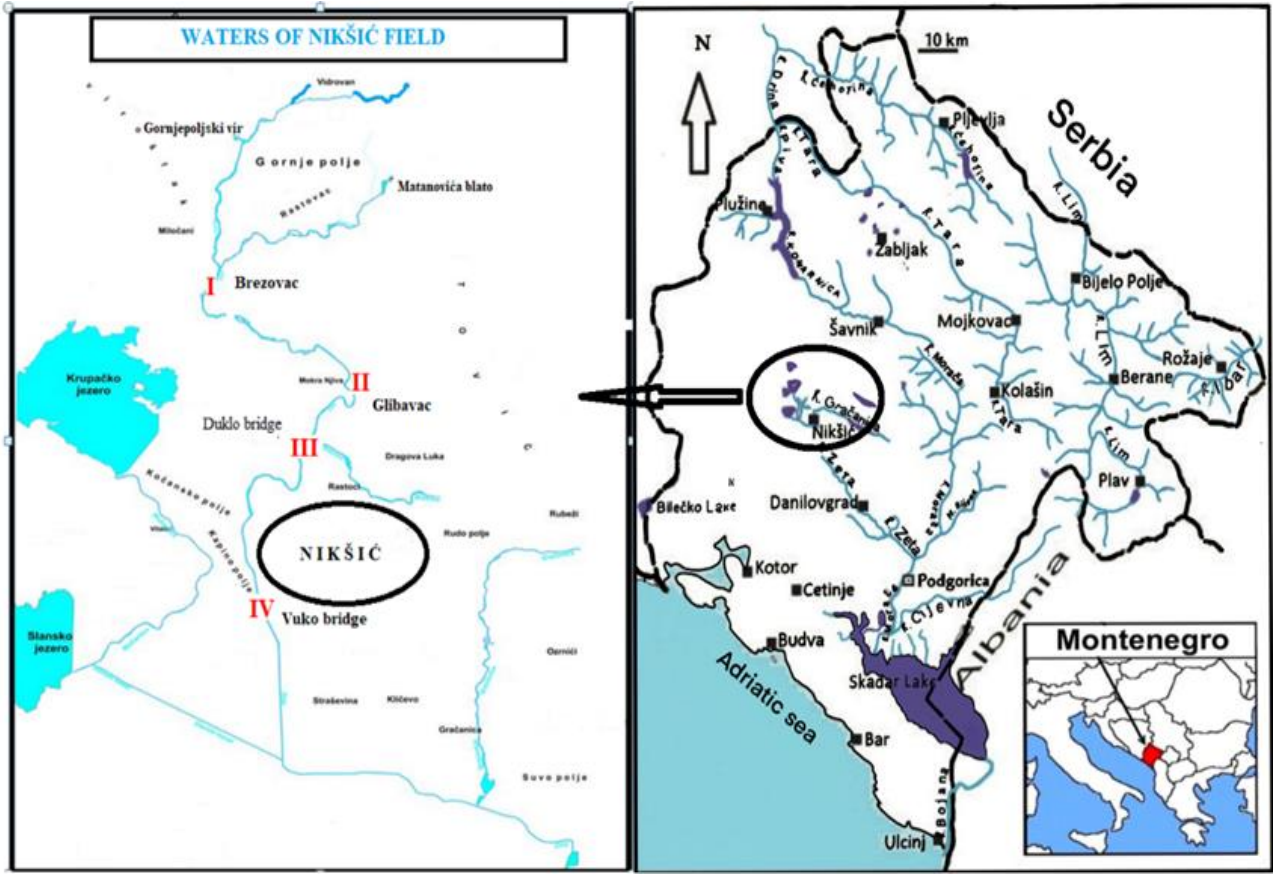

Figure 1. Map of water bodies in Nikšić field (sampling sites marked with Roman numerals)

The width of the riverbed is $7-25 \mathrm{~m}$, and the water depth is 0.2 to $5 \mathrm{~m}$. Different trees and shrubs grow on the banks of the river, mostly willows (Salix spp.) and poplars (Populous spp.). The bank of the river is in some places overgrown with reeds - Phragmites sp. The riverbed has different water depths, the lotic and lentic areas alternate. The bottom of the river is covered with aquatic vegetation $(70 \%)$ which consists mainly of species of the genus Potamogeton, to a lesser extent the species Miriofilum sp. and Ranunculus sp. The fauna of the bottom of the river Zeta consists of representatives of Gastropods, Oligochaeta and insect larvae: Ephemeroptera, Plecoptera, Trichoptera, Chironomidae, Simulidae, etc. (Marić and Rajković, 2004). According to Marić (2019) were found six species of fishes: Thimallus thimallus; Salmo farioides; Salmo labrax; Oncorhynchus mykiss Squalius plaryceps; Phoxinus sp.

Noble crayfish were collected from four localities on the Zeta River (Figure 1) the first locality, Gornje Polje, is located in the immediate vicinity where two rivers, Rastovac and Bistrica, join and form the river Zeta. There are no industrial pollutants in this area. The 2nd locality (II), Mokra Njiva, 2-3 km away from the main road Nikšić - Plužine. The Brezovik hospital located upstream $2 \mathrm{~km}$ from this site, and it has a collector for water purification. The 
locality Duklov most (III), is located in the city zone. Upstream from this locality, the river Bistrica flows into the river Zeta. It flows through the industrial zone of the city and brings waste of different origin. The fourth locality (IV), Vukov most (bridge), is just below the city. All industrial waters and household waters upstream reach in the river.

\section{Crayfish collection and measurements and statistical analysis}

Our study was conducted in the summer (July) 2013 using a commercial fishing gears - the traps or fyke nets in the area of the upper course of the Zeta River, Montenegro. Researching area included 4 localities between which the distance is about $3 \mathrm{~km}$. A total of 99 specimens of the Noble Crayfish (Astacus astacus L.) in the River Zeta were caught. All specimens (fresh) were measured for total length (TL, in $\mathrm{cm}$ ) and weight (W, total wet weight in $\mathrm{g}$ ) to the nearest $0.01 \mathrm{~g}$ by an electronic balance. The total length (TL) of each specimens (measured using digital caliper to the nearest $0.01 \mathrm{~mm}$ ) was taken from the beginning of the rostrum to the end of the telson. All specimens (sexually mature) of the Noble Crayfish caught at four site were larger than $9.5 \mathrm{~cm}$. Differences between 4 sites and samples were analysed by Analysis of Variance (ANOVA). The statistical analyses were considered at a significance level of $1 \%(\mathrm{P}<0.01$.

Tissue samples of the caudal (tail) muscle and exoskeleton (from carapace) were taken, than milled using an electric grinder and stored in airtight polyethylene bottles at $-18{ }^{\circ} \mathrm{C}$ until chemical analyses. All chemical analyses were performed in laboratory of Center for Eco-toxicological Research (CETI, Podgorica). Three parallel determinations were carried out for each parameter. Concentrations of analysed trace elements were expressed on a wet weight basis, as $\mathrm{mg} \mathrm{kg}^{-1}$. The limits of quantification (LOQ) were: $0.1 \mathrm{mg} \mathrm{kg}^{-1}$ for $\mathrm{Pb} ; 0.01 \mathrm{mg}$ $\mathrm{kg}^{-}{ }^{1}$ for $\mathrm{Cd}$; $0.06 \mathrm{mg} \mathrm{kg}^{-1}$ for As; $0.025 \mathrm{mg} \mathrm{kg}^{-1}$ for Co and Cr; $0.02 \mathrm{mg} \mathrm{kg}^{-1}$ for $\mathrm{Ni} ; 0.2 \mathrm{mg} \mathrm{kg}^{-1}$ for $\mathrm{Fe}, \mathrm{Mn}, \mathrm{Cu}$ and $\mathrm{Zn}$; $0.001 \mathrm{mg} \mathrm{kg}^{-1}$ for $\mathrm{Hg}$; and $5 \mathrm{mg} \mathrm{kg}^{-1}$ for $\mathrm{Ca}$ and Mg. Detailed procedure was described by Rakocevic et al (2018). Data analyses were performed with using Statistica 8.0 software (StatSoft, USA). Data are given as Mean $\pm \mathrm{SD}$ (standard deviation).

\section{RESULTS}

The Noble crayfish caught ranged in total length from 9.50 to $14.60 \mathrm{~cm}$ and in weight from 23.50 to $125.90 \mathrm{~g}$. No significant differences were found between the average length and weight of the investigated Noble crayfish from four localities $((\mathrm{P}>0.05)$.

The concentrations of the relevant metals (15 metals) analysed in the muscle and exoskeleton - carapace from four localities in the Zeta River are presented in Table 1. Cadmium, $\mathrm{Pb}$ and $\mathrm{Mo}$, if present, were in concentrations below the detection limit. A wide range of concentrations of some metals were found in the analysed tissues in the muscle: As < 0.025-16.0, Ca 25.2-116.1, Hg 33.1-97.1, Si 15.6-43.1 and in the exoskeleton Al 9.6-68.9, Ca 68.9-141.1, Fe 26.7-58.5, Mn 37.4-84.4. 
A narrow range of concentrations was detected for each of the other trace metals in the muscle $\mathrm{Al} 3.7-13.1, \mathrm{Cr}$ undetected-1.1, $\mathrm{Cu}$ 8.6-21.7, Fe 6.0-17.9, $\mathrm{K}$ 2.3-8.2, Mn 2.2-14.2, Mg 200.1-253.5, Na 0.8-2.2, Ni 0.04-0.14, Sn 0.2-1.6, Zn 17.6-19.8 and in the exoskeleton As 7.8-15.6, $\mathrm{Cu} 17.5-22.2, \mathrm{Hg} 6.2-15.1, \mathrm{~K} \mathrm{1.9}$ 3.3, Mg 1.0-2.5, Na 1.9-2.7, Ni 0.03-0.06, Sn 27.9-40.8, Si 40.6-46.8, Zn 11.318.8. $\mathrm{Cr}$ was found only in the second locality in both carapace and abdominal muscle but was higher in the latter.

As shown in table $1, \mathrm{Al}, \mathrm{Cu}, \mathrm{Ca}, \mathrm{Fe}, \mathrm{Mn}, \mathrm{Sn}$ and $\mathrm{Si}$ concentrations were significantly higher in carapace of $A$. astacus than abdominal muscle. $\mathrm{Mg}, \mathrm{Hg}, \mathrm{K}$ and $\mathrm{Zn}$ mainly accumulated in crayfish muscle. Only two metals ( $\mathrm{Hg}$ and $\mathrm{Mg}$ ) were significantly higher in abdominal muscle of $A$. astacus than carapace. $\mathrm{Mg}$ primarily accumulated in crayfish abdominal muscle at similar levels for all sites (Tables 1). No significant differences were found for the other trace elements content among the sampled tissues.

Table 1. Concentrations of 15 metals in the muscle and chitin- exsosceleton samples from different locations. Data are given as Mean \pm SD.

\begin{tabular}{|c|c|c|c|c|c|c|c|c|}
\hline Locality & \multicolumn{3}{|c|}{1.} & \multicolumn{2}{c|}{2.} & \multicolumn{2}{c|}{3.} & \multicolumn{2}{c|}{4} \\
\hline Metals/in & muscle & chitin & muscle & chitin & muscle & chitin & muscle & chitin \\
\hline $\mathrm{Al}^{\#}$ & $3.7 \pm 2.01$ & $9.6 \pm 5.50$ & $13.1 \pm 6.33$ & $68.9 \pm 9.82$ & $11.4 \pm 6.23$ & $20.6 \pm 6.05$ & $8.5 \pm 5.88$ & $49.8 \pm 7.54$ \\
\hline $\mathrm{As}$ & $<0.025$ & $7.8 \pm 4.82$ & $16.0 \pm 7.45$ & $10.4 \pm 7.23$ & $12.8 \pm 7.03$ & $10.8 \pm 6.24$ & $12.2 \pm 6.06$ & $15.6 \pm 6.81$ \\
\hline $\mathrm{Ca}^{\#}$ & $25.2 \pm 5.87$ & $68.9 \pm 12.34$ & $36.7 \pm 8.79$ & $141.1 \pm 15.38$ & $37.3 \pm 7.54$ & $56.2 \pm 10.16$ & $116.1 \pm 12.89$ & $49.9 \pm 10.84$ \\
\hline $\mathrm{Cr}$ & $/$ & $/$ & $1.1 \pm 0.32$ & $<0,02$ & $/$ & $/$ & $/$ & $/$ \\
\hline $\mathrm{Cu}^{\#}$ & $8.6 \pm 2.88$ & $17.5 \pm 3.61$ & $12.9 \pm 3.98$ & $22.2 \pm 5.04$ & $21.7 \pm 6.32$ & $17.9 \pm 3.76$ & $15.4 \pm 4.13$ & $20.7 \pm 4.87$ \\
\hline $\mathrm{Hg}^{\#}$ & $85.9 \pm 43.58$ & $10.7 \pm 4.65$ & $97.1 \pm 34.12$ & $12.5 \pm 6.72$ & $59.3 \pm 9.58$ & $6.2 \pm 3.61$ & $33.1 \pm 8.62$ & $15.1 \pm 6.81$ \\
\hline $\mathrm{Fe}^{\#}$ & $6.0 \pm 5.21$ & $58.5 \pm 41.86$ & $13.2 \pm 10.29$ & $48.8 \pm 40.34$ & $14.4 \pm 12.65$ & $26.7 \pm 20.43$ & $17.9 \pm 16.82$ & $38.4 \pm 28.21$ \\
\hline $\mathrm{K}$ & $2.3 \pm 1.11$ & $2.1 \pm 0.93$ & $4.0 \pm 1.74$ & $3.3 \pm 1.23$ & $4.0 \pm 1.65$ & $2.0 \pm 0.90$ & $8.2 \pm 4.66$ & $1.9 \pm 0.96$ \\
\hline $\mathrm{Mn}^{\#}$ & $2.2 \pm 0.55$ & $60.9 \pm 20.11$ & $3.7 \pm 1.08$ & $37.4 \pm 6.24$ & $6.8 \pm 2.45$ & $63.1 \pm 8.33$ & $14.2 \pm 4.56$ & $84.4 \pm 25.66$ \\
\hline $\mathrm{Mg}^{\#}$ & $200.1 \pm 43.76$ & $1.6 \pm 0.22$ & $222.8 \pm 38.93$ & $2.5 \pm 0.72$ & $242.0 \pm 44.37$ & $1.6 \pm 0.75$ & $253.5 \pm 56.88$ & $1.0 \pm 0.0 .20$ \\
\hline $\mathrm{Na}$ & $0.8 \pm 0,21$ & $1.9 \pm 0.28$ & $1.7 \pm 0.31$ & $2.7 \pm 0.33$ & $2.1 \pm 0.32$ & $2.0 \pm 0.24$ & $2.2 \pm 0.43$ & $2.3 \pm 0.36$ \\
\hline $\mathrm{Ni}$ & $0.04 \pm 0.02$ & $0,05 \pm 0.4$ & $0.10 \pm 0.09$ & $0.05 \pm 0.03$ & $0.14 \pm 0.12$ & $0.06 \pm 0.03$ & $0.05 \pm 0.03$ & $0.03 \pm 0.02$ \\
\hline $\mathrm{Sn}^{\#}$ & $0.2 \pm 0.09$ & $27.9 \pm 18.65$ & $0.31 \pm 0.08$ & $38.6 \pm 25.82$ & $0.4 \pm 0.09$ & $39.7 \pm 22.41$ & $1.6 \pm 0.02$ & $40.8 \pm 19.94$ \\
\hline $\mathrm{Si}^{\#}$ & $15.6 \pm 10.17$ & $46.8 \pm 12.03$ & $43.1 \pm 20.65$ & $40.6 \pm 10.56$ & $24.4 \pm 10.28$ & $43.0 \pm 11.62$ & $34.9 \pm 12.88$ & $40.9 \pm 14.53$ \\
\hline $\mathrm{Zn}^{\#}$ & $18.0 \pm 9,78$ & $13.3 \pm 5.49$ & $19.8 \pm 8.76$ & $15.7 \pm 6.38$ & $17.6 \pm 7.34$ & $11.3 \pm 5.11$ & $18.9 \pm 10.56$ & $18.8 \pm 7.68$ \\
\hline & & & & & & & & \\
\hline
\end{tabular}

The concentrations of fifteen elements in the noble crayfish were examined and the results showed the wide variations for the concentration of the trace of almost all elements among four localities (Table 1). The concentration of heavy metals in muscle showed significant differences between sampling sites (one-way ANOVA, all $\mathrm{p}<0.01$ ), and was higher at Vukovog mosta (4 sites), while first sites exhibited a lower metal pollution scenario. As shown in table 1, the smallest amount were found for twelve metals (80\%): As; $\mathrm{Al} ; \mathrm{Cu} ; \mathrm{Ca} ; \mathrm{Fe} ; \mathrm{Mn} ; \mathrm{K} ; \mathrm{Ni}$; Na; $\mathrm{Sn}$; $\mathrm{Si}$ and $\mathrm{Mg}$ in the muscles, while the highest values were not found at the first locality. The concentrations of $\mathrm{Fe}$ and $\mathrm{Si}$ in exosceleton of crayfish from first 
locality was highest comparing to the other three localities, and at the fourth only for $\mathrm{Hg}$ and $\mathrm{Mn}$.

The concentrations of four essential elements ( $\mathrm{Mn}, \mathrm{Fe}, \mathrm{Cu}$ and $\mathrm{Zn})$ in the noble crayfish showed a similar range of concentrations on the longitudinal profile. Observed on the longitudinal profile, $\mathrm{Mn}$ (and Sn) have a slight increase in both tissues, and $\mathrm{Mg}$ only in the muscles, but all nonsignificant. $\mathrm{Fe}$ and $\mathrm{Ca}$ in abdominal muscle increase going downstream, and in chitin the values are higher for both elements in the first two localities. In contrast, the values for $\mathrm{Cu}$ in muscle are higher in the other two localities downstream. Only the concentration of $\mathrm{Hg}$ in the muscles decreases significantly downstream, but there is no regularity in the exoskeleton.

At the second locality - Mokra Njiva, the lowest values were not detected in the meat of river crayfish, and the largest amount was registered for two metals: $\mathrm{Hg}$ and $\mathrm{Si}$. In the chitin cuticle at site II, $\mathrm{Al}, \mathrm{Fe}$ and $\mathrm{Ca}$ have the highest values. Chromium was detected only at this site. At site III, Duklov most, the highest amount was found only for $\mathrm{Ni}$ in abdominal muscle of noble crayfish. Potassium and Manganese increase downstream, properly in muscle, while in chitin they do not increase properly.The concentrations of $\mathrm{Fe}, \mathrm{Mn}, \mathrm{Mg}$ and $\mathrm{K}$ in abdominal muscle of crayfish from last sites was highest comparing to the other three regions.

\section{DISCUSSION}

To assess the health risk to the crayfish-consuming population, we investigated metals (18) in crayfish tissues (exoskeleton, abdominal muscle) in the upper part of the Zeta River. The Zeta River receives domestic and industrial untreated wastewaters from Nikšić city and surrounding villages during the last decades. In this study, the degree of metal accumulation in the tissues of crayfish samples collected from the Zeta River was investigated, because Crayfish may be used as an environmental indicator because their tissues tend to accumulate metals, including heavy ones (Anderson et al. 1997b). Almost all studies on the distribution of metals in crustacean tissues have shown that the hepatopancreas is the most important storage organ for trace elements and then gills or exoskeleton (Pourang and Dennis 2005, Alcorlo et al. 2006., Mistri et al 2020, FikirdesiciErgen et al. 2019). The abdominal muscle has consistently been found in the literature to be the tissue containing the lowest concentration of metals (Anderson et al. 1997; Mackevièienë 2002, Naghshbandi et al. 2007, Kouba et al. 2010 Protosowicki et al 2013), and our results also agree with this. According to Naghshbandi et al (2007) only Zn concentrations were significantly higher in abdominal muscle of A. leptodactylus than carapace. Our analyses indicated that seven metals was accumulated in the greatest amounts in the exoskeleton (Table 1). Several metals were several times larger in the exoskeleton than in the muscles, e.g. Al, Fe, Sn. According by Fikirdesica-Ergen et al. (2019) Cu, Zn, $\mathrm{Mn}, \mathrm{Fe}$ and $\mathrm{Al}$ are almost 10 times higher in exoskeleton than in muscle. $\mathrm{Al}$ is a metal abundant in nature and there was common belief that it does not have a negative effect on human health (Ranau et al. 2001). High levels of metals in the 
exoskeletonon may be due to the absorption of metals from water (Anderson et al. $1997 \mathrm{a}, \mathrm{b})$ or the fact that it is the route for both absorption and excretion of metals from the organism (Mackevièienë 2002). The opposite results for $\mathrm{Cu}, \mathrm{Zn}$ and As were denoted by Stanek et al. (2017) for spiny-cheek crayfish and Mistri et al. (2020) for Procambarus clarkii. It is generally known that the chitin cuticle has a protective role, it is logical to expect that it contains the most heavy metals, which means that the cuticle, in addition to mechanical or physical protection (from injuries), protects internal organs and meat from harmful metals. Therefore, it has a special role in young crabs because they change their clothes five or six times during the first year (Reynolds, 2002).

Only two metals ( $\mathrm{Hg}$ and $\mathrm{Mg}$ ) were significantly higher in abdominal muscule of $A$. astacus from the River Zeta, than exoskeleton. In crayfish, mercury is accumulated largely in muscle (Simon et al. 2000; Loukola-Ruskeeniemi et al. 2003; Kouba et al. 2010) and according to Wiener et al. (2003) the mercury predominantly accumulates and in fish muscle. According to Kouba et al. (2010) and nickel accumulated largely in muscles and exoskeleton, respectively. Nickel accumulated approximately equally in both tissues of noble crayfish from Zeta river. The values of $\mathrm{Hg}$ and $\mathrm{Mn}$ were very high at each site studied $(\mathrm{Hg}-97.1$ to $33.1 \mathrm{mg}, \mathrm{Mg}-253.5$ to $200.1 \mathrm{mg}$ ) in muscle. Mercury is explicitly toxic substances, although their high concentrations are tolerated by organism. However, decapods are resistant organisms to environmental contamination, and even relatively high concentrations of metals (in this example $\mathrm{Hg}$ ) are usually not responsible for their mortality (Kouba et al. 2010). High level some metals in the Noble crayfish from the river Zeta suggesting the pollution of the environment by heavy metals. The accumulation of metals in crayfish tissues is dose- and timedependent, and therefore may be reflective of the levels of metals in the environment (Antón et al. 2000; Sánchez-López et al. 2004; Alcorlo et al. 2006; Allert et al. (2009). However, the measured values for $\mathrm{Pb}, \mathrm{Cd}$ and $\mathrm{Cr}$ were below the threshold, thus suggesting limited contamination in the Nikšić area. No significant differences were found for the other trace elements content among the sampled tissues. With regard to the concentrations, the metals formed the following order in muscle: $\mathrm{Mg}>\mathrm{Hg}>\mathrm{Ca}>\mathrm{Si}>\mathrm{Zn}>\mathrm{Cu}>\mathrm{Fe}>\mathrm{As}>\mathrm{Al}>\mathrm{Mn}>$ $\mathrm{K}>\mathrm{Na}>\mathrm{Sn}>\mathrm{Ni}>\mathrm{Cr}>$, and in exoskeleton: $\mathrm{Ca}>\mathrm{Mn}>\mathrm{Fe}>\mathrm{Si}>\mathrm{Sn}>\mathrm{Al}>\mathrm{Cu}$ $>\mathrm{Zn}>\mathrm{As}>\mathrm{Hg}>\mathrm{K}>\mathrm{Na}>\mathrm{Mg}>\mathrm{Ni}>\mathrm{Cr}$.

The observed order of increasing metal concentrations in crayfish organs is no consistent with their content in the lithosphere and hydrosphere provided by Information on the state of the environment in Montenegro for 2010, Ministry of Sustainable Development and Tourism 2010, Environmental Protection Agency of Montenegro). This shows that these arrays of metals are a consequence of pollution in this area. However, Iron, Mn and Al (in the Zeta river basin) are naturally abundant in sediments in Montenegro. Contamination can originate from a wide variety of anthropogenic sources such as disposal of high metal wastes in improperly protected landfills, land application of fertilizer, animal manures, sewage sludge, compost, pesticides and coal combustion residues 
located in the Zeta river basin. According to Wuana and Okieimen (2011). most commonly found at contaminated sites are: $\mathrm{Pb}, \mathrm{Cr}, \mathrm{As}, \mathrm{Zn}, \mathrm{Cd}, \mathrm{Cu}, \mathrm{Hg}$, and $\mathrm{Ni}$. According to Bagatto and Alikhan (1987) the content of zinc in the body of a crayfish is naturally high. The concentrations of $\mathrm{As}, \mathrm{Cr}, \mathrm{Hg}$ and $\mathrm{Ni}$ in the present study were higher than the maximum permissible limits for human consumption established by Montenegrin legislation. Although no EU threshold limit for human consumption of crayfish muscle is established for $\mathrm{Cu}$ and $\mathrm{Zn}$, other national regulations set maximum limits, e.g. for $\mathrm{Cu}$ at $20 \mathrm{mg} \mathrm{kg}-1$ w.w. in edible mass (Spain: Boletin Oficial del Estado 195, 15/8/1991), for Zn at $70 \mathrm{mg}$ $\mathrm{kg}-1$ w.w. (U.S. Food and Drugs Administration), as reported by Alcorlo et al. (2006) and our results also agree with this. The content of these metals in crayfish organs varied depending on where they were caught. The highest metals content was detected in the downstream samples (3 and 4) close to main wastewater discharge point suggesting an anthropogenic contribution to total metals concentrations in muscle of crayfish from River Zeta. Only one metals - Hg were significantly higher on first and second sites in abdominal muscle of A. astacus, while crayfish collected upstream showed lower values for all heavy metals. The Zeta River receives domestic and industrial untreated wastewaters from Nikšić city and surrounding villages during the last decades. Noble crayfish does not have a large home range, hence migrations do not influence the level of metals accumulated in its tissues (Bohl 1999). Specimens are therefore representative of the locations in which they are caught.

Mercury concentrations were similar among sites. Based on a comparison, we found higher $\mathrm{Hg}$ concentrations with respect to those found by Finerty et al. (1990), Hothem et al. (2007) etc. from highly industrialized areas. We assume that the source of $\mathrm{Hg}$ pollution comes from medical waste that is uncontrolled discharged near the riverbed, or is derived from pesticides. The pollution of the environment by heavy metals is a result of various industrial activities and is also a multi-element problem in many areas of the world (Waisberg et al. 2003., John et al. 2008). The highest $\mathrm{Al}, \mathrm{As}, \mathrm{Ni}$ and $\mathrm{Si}$ concentrations in crayfish were found near the contaminated sediments at Zeta River. The high values draw attention to the land-based domestic and industrial inputs. The Zeta River receives domestic and industrial untreated wastewaters from Nikšić city and surrounding villages during the last decades. Agriculture takes important place for the economic value of the study area. Conservative fungicides that contain $\mathrm{Cu}$ are mainly used for fruits plantations and green-houses around the study area and composed fertilizer enriched with $\mathrm{Zn}$ and microelements fertilizer contains $\mathrm{Mn}$ are also widely used for farming around study area. Measuring $\mathrm{Hg}, \mathrm{Pb}, \mathrm{Cr}, \mathrm{As}$, $\mathrm{Ni}$ and $\mathrm{Sn}$ levels in crayfish from the Zeta river is important to demonstrate the potential risk to humans if the crayfish are consumed.

Content of some toxic metals in the muscle of Noble crayfish from River Zeta exceed the statutory limits for fish and crayfish intended for human consumption. Therefore, the crayfish from this region, in general, are not safe for human consumption. The average $\mathrm{Hg}$ values were higher than the limits of 
Montenegro Official Gazette (2009) and according to EU limits (European Union Regulation). Because contamination of crayfish by heavy metals may pose a real risk to consumer, therefore, it is important to have knowledge on heavy metals levels in the tissues of crayfish used for food, and further investigation should be continued in future studies. Although other studies have shown that muscle tissue contains the lowest heavy metal levels compared with other tissues, muscle tissue is an important measure from a health view point since it is the most edible part of the crayfish (Anderson et al.,1997; Alcorlo et al.,2006). Environmental pollution by heavy metals is an escalating problem worldwide.

\section{CONCLUSIONS}

This study was carried out to provide information on heavy metal concentrations in noble crayfish which were consumed by local people and have commercially importance. Crayfish accumulated higher levels of heavy metals in the exosceleton than in the muscle, consistently with previous studies. The levels of certain metals accumulated in the abdominal muscle exceeded the threshold values established by the EU (e.g. Hg) legislation. Measuring The accumulation of metals in crayfish tissues from the Zeta river is important to demonstrate the potential risk to humans if the crayfish are consumed. Our results also evidence that Noble crayfish living in the River Zeta are not suitable for human consumption. Because contamination of crayfish by heavy metals may pose a real risk to consumer, therefore, it is important to have knowledge on heavy metals levels in the tissues of crayfish used for food, and further investigation should be continued in future studies. To the legislators, we propose A. astacus for use as a bio indicator of heavy metals due to its ability to accumulate these environmental pollutants.

\section{ACKNOWLEDGEMENTS}

We thank to anonymous reviewers, whose constructive comments greatly improved this paper.

\section{REFERENCES}

Alcorlo P, Otero M, Crehuet M, Baltanás A, Montes C. (2006): The use of the red swamp crayfish (Procambarus clarkii, Girard) as indicator of the bioavailability of heavy metals in environmental monitoring in the River Guadiamar (SW, Spain). Science of the Total Environment 366:380-390. DOI:10.1016/j.scitotenv.2006.02.023.

Allert, A. L., Fairchild, J. F., DiStefano, R. J., Schmitt, C. J.,Brumbaugh, W. G., \& Besser, J. M. (2009): Ecological effects of lead mining on Ozark streams: in-situ toxicity to woodland crayfish (Orconectes hylas). Ecotoxicology and Environmental Safety, 72, 1207-1219.

Anderson M.B., Preslan J.E., Jolibois L., Bollinger J.E., George W.J. (1997a): Bioaccumulation oflead nitrate in red swamp crayfish (Procambarus clarkii). Journal of Hazardous Materials 54(1-2), 15-29

Anderson M.B., Reddy P., Preslan J.E., Fingerman M., Bollinger J.E., Jolibois L., Maheshwarudu G., George W.J. (1997b): Metal accumulation in crayfish Procambarus clarkii, exposed to a petroleum - contaminated Bayou in Louisiana. Ecotoxicology and Environmental Safety, 37(3), 67-72. 
Antòn A, Serrano T, Angulo E, Ferrero G, Rallo A. (2000): The use of two species of crayfish as environmental quality sentinels: The relationship between heavy metal content, cell and tissue biomarkers and physico-chemical characteristics of the environment. Science of the Total Environment 247:239-251. DOI: 10.1016/S00489697(99)00493-3.

Bagatto, G., \& Alikhan, M. A. (1987): Zinc, iron, manganese and magnesium accumulation in crayfish populations near copper-nickel smelters at Sudbury, Ontario, Canada. Bulletin of Environmental Contamination and Toxicology, 38, 1076-1081.

Bohl, E. (1999). Motion of individual noble crayfish Astacus astacus in different biological situations: in-situ studies using radio telemetry. Freshwater Crayfish, 12, 677-687.

Bonada N, Prat N, Resh VH, Statzner B. (2006): Developments in aquatic insect biomonitoring: A comparative analysis of recent approaches. Annual Review of Entomology 51:495-523. DOI: 10.1146/annurev.ento.51.110104.151124.

Hothem, R. L., Bergen, D. R., Bauer, M. L., Crayon, J. J., \& Meckstroth, A. M. (2007): Mercury and trace elements in crayfish from Northern California. Bulletin of Environmental Contamination and Toxicology, 79, 628-632.

Fikirdesici-Ergen, S. Mutlu-eyison, H and Altindag. A (2019): Metal accumulation profile in crayfish tissues from Çomar stream. Communications Faculty of Sciences University of Ankara Series C: Biology 28 (1), 114-127 DOI: 10.1501/commuc_0000000234

Finerty, M. W., Madden, J. D., Feagley, S. E., \& Grodner, R. M. (1990): Effect of environs and seasonality on metal residues in tissues of wild and pond-raised crayfish in southern Louisiana. Archives of Environmental Contamination and Toxicology, 19, 94-100.

John, R.; Ahmad, P.; Gadgil, K.; Sharma, S. (2008): Effect of cadmium and lead on growth, biochemical parameters and uptake in Lemna polyrrhiza L. Plant Soil and Environment, 54(6), 262-270.

Kouba A., Buøiè M, Kozák P. (2010): Bioaccumulation and effects of heavy metals in crayfish. Water Air Soil Pollution, 211: 5-16.

Loukola-Ruskeeniemi, K., Kantola, M., Halonen, T., Seppänen, K., Henttonen, P., Kallio, E., et al. (2003): Mercurybearing black shales and human $\mathrm{Hg}$ intake in eastern Finland: impact and mechanisms. Environmental Geology, 43, 283-297.

Mackevièienë G. (2002): Bioaccumulation of heavy metals in noble crayfish (Astacus astacus L.) tissues under aquaculture conditions. Ekologija (Vilnius), 2, 79-82.

Marić, D. (2018): The Ichthyofauna of Lake Skadar/Shkodra: Diversity, Economic Significance, Condition, and Conservation Status. In Pešić, V. et al. (eds.), The Skadar/Shkodra Lake Environment. Hdb Env Chem, Springer International Publishing AG. pp. 363-381.

Marić, D. (2019): Fauna slatkovodnih riba (Osteichthyes) Crne Gore - Fauna of Freshwater Fish (Osteichthyes) of Montenegro. Crnogorska Akademija Nauka i Umjetnosti, (Montenegrin Academy of Sciences and Arts), ed. G.S.Karaman, spec. ed. No 149, 419 p. Podgorica,

Marić, D. \& Rajković, M. (2004): Competitors and Predators the Cause of Crayfish (Astacus astacus L.) Numerosity Decrrease in the Waters of Nikšić Region. Natura Montenegrina, 3: 101-111. 
Mistri, M., Munari, C., Pagnoni, A., Chenet, T., Pasti L. \& Cavazzini A. (2020): Accumulation of trace metals in crayfish tissues: is Procambarus clarkii a vector of pollutants in Po Delta inland waters?, The European Zoological Journal, 87:1, 4657, DOI:10.1080/24750263.2020.1717653

Naghshbandi, N. Zare, S., Heidari,R. And Razzaghzadeh, S. (2007): Concentration of Heavy Metals in Different Tissues of Astacus leptodactylus from Aras Dam of Iran. Pakistan Journal of Biological Sciences. 10 (21): 3956-3959

Pešić, V., Grabowski, M., Hadziablahovic, S., Maric. D. and Paunović, M. (2019): The Biodiversity and Biogeographical Characteristics of the River Basins of Montenegro In book: The Rivers of Montenegro, Edition: The Handbook of Environmental Chemistry, Springer Nature Switzerland AG., DOI: 10.1007/698_2019_414

Pourang N. (1996): Heavy metal concentrations in surficial sediments and benthic macroinverte-brates from Anzali wetland, Iranian Hydrobiologia 331:53-61. DOI: 10.1007/BF00025407

Pourang N., Dennis J.H. (2005): Distribution of trace elements in tissues of two shrimp species from the Persian Gulf and roles of metallothioneinen in their redistribution. Environment International, 31(3):325-41

Protasowicki M, Własow T, Rajkowska M, Polna M, Bernad A (2013): Metal concentrations in selected organs of crayfish-Orconectes limosus and Pacifastacus leniusculus from Mazurian Lakes. Journal of Elementology, 18(4):683 - 694. doi:10.5601/jelem.2013.18.4.537

Rainbow, P. S. (2007): Trace metal bioaccumulation: Models, metabolic availability and toxicity, Environment International, 33 (4), 576-582. doi: 10.1016/j.envint.2006.05.007.

Rakocevic, J., Sukovic, D., Maric, D. (2018): Distribution and Relationships of Eleven Trace Elements in Muscle of Six Fish Species from Skadar Lake (Montenegro). Turkish Journal of Fisheries and Aquatic Sciences, 18: 647-657.

Ranau, R., Oehlenschläger, J., \& Steinhart, H. (2001): Aluminium content in edible parts of seafood. European Food Research and Technology, 212, 431-438.

Reynolds, J.D. (2002): Growth and reproduction. U: Holdich DM (ed.) Biology of freshwater crayfish. Bleckwell science, Oxford, 152-192.

Sánchez López FJ, Gil García MD, Martínez Vidal JL, Aguilera PA, Garrido Frenich A (2004): Assessment of metal contamination in Dońana National Park (Spain) using crayfish (Procamburus clarkii). Environmental Monitoring and Assessment, 93(13):17-29. doi:10.1023/B:EMAS.0000016789.13603.e5

Simon, O., Ribeyre, F., \& Boudou, A. (2000): Comparative experimental study of cadmium and methylmercury trophic transfers between the asiatic clam Corbicula fluminea and the crayfish Astacus astacus. Archives of Environmental Contamination and Toxicology, 38, 317-326.

Stanek M., Dąbrowski J., Różański S., Janicki B. and Długosz J. (2017): Heavy Metals Bioaccumulation in Tissues of Spiny-Cheek Crayfish (Orconectes limosus) from Lake Gopło: Effect of Age and Sex. Bulletin of Environmental Contamination and Toxicology, 98 (5):740-746.

Vamerali, T., Bandiera, M., Mosca, G. (2010): Field crops for phytoremediation of metal contaminated land. Environmental Chemistry Letter, 8: 1-17.

Waisberg M, Joseph P, Hale B, Beyersmann D. (2003): Molecular and cellular mechanisms of cadmium carcinogenesis. Toxicology 192:95-117. 10.1016/s0300483x (03)00305-6 - 
Wiener, J.G., Krabbenhoft, D.P., Heinz, G.H., \& Scheuhammer, A.M. (2003): Ecotoxicology of mercury. In D.J. Hoffman, B.A. Rattner, G.A. Burton, Jr. \& J. Cairns (Eds), Handbook of Ecotoxicology, pp. 409-464. CRC Press, Boca Raton, FL. http://dx.doi.org/ 10.1201/9781420032505.ch16

Wuana RA, Okieimen FE. (2011): Heavy metals in contaminated soils: A review of sources, chemistry, risks and best available strategies for remediation. ISRN Ecology 2011:1-20. DOI: 10.5402/2011/402647.

Zhou Q, Zhang J, Fu J, Shi J, Jiang G. (2008): Biomonitoring: An appealing tool for assessment of metal pollution in the aquatic ecosystem. Analytica Chimica Acta 606:135-150.

Official Gazette of Montenegro (2009): Regulation of permitted levels of trace metals, mycotoxins and other substances in food. No 81/2009. Official Gazette RS (2011). Regulation on quantity of pesticides, metals, metalloids, and other toxic substances, chemotherapeutics, anabolics, and other substances which can be found in food. No 28/2011. 